DOI https://doi.org/10.18551/rjoas.2018-01.19

\title{
THE EFFECT OF BRAND IMAGE AND PRODUCT ON CUSTOMER SATISFACTION AND WILLINGNESS TO PAY AT COFFEE BEAN SURABAYA
}

\author{
Budi Indra Setya*, Harsono Soni \\ STIE Perbanas Surabaya, Indonesia \\ *E-mail: indrasetyabudi1988@gmail.com
}

\begin{abstract}
The aim of research is to determine factors influencing willingness to pay on Coffee Bean's customers. This research used structural equation modeling with WarpPLS 5.0 software as the analysis tool. Before the analysis of hypothesis testing, outer model and inner model testing was firstly conducted. Outer model testing examined the correlation between constructs with latent variables of the research including discriminate validity, composite reliability, and average variance extracted. The data collection used convenience sampling method by randomly choosing all customers that purchase in Coffee Bean at Pakuwon Supermall Surabaya. The results showed that the proposed hypotheses were all accepted except one hypothesis on the correlation between the products and the willingness to pay in which had no significant correlation.
\end{abstract}

\section{KEY WORDS}

Brand image, product, customer satisfaction, willingness to pay.

Coming to the year of 2016, the ASEAN Economic Community (AEC) has been running even though only for one year. The ASEAN Community Economic program (AEC) applies the free trade system. Indonesia and all ASEAN members including Malaysia, Thailand and Vietnam have agreed on the agreement of ASEAN Economic Community (AEC).

By the enactment of the ASEAN Economic Community (AEC), investment, skilled labor, goods and services can be freely traded without any tariff or non-tariff barriers. As the result, the competition level among ASEAN countries will be tougher. By the enactment of the ASEAN Economic Community (MEA) with the principle of free trade, the ASEAN countries must improve the quality of their domestic products in order to compete with other ASEAN countries including Indonesia. If it is neglected, then other countries' products will invade Indonesian domestic market. A lot of products from other countries worryingly threaten the domestic industry which will eventually increase the trade balance deficit.

One of the industries in Indonesia that experiences a fairly competitive competition is the food and beverage industry. In Indonesia, the food and beverage industry is a café. The existence of ASEAN Economic Community (MEA) cafes in Indonesia will increase the number of its competitors such as franchise cafes from other countries that will enter to Indonesia. Therefore, Indonesian cafes must improve in order to face the increasing competition. To overcome this problem, most Indonesian cafes have anticipated it by improving product and service quality. One of them is applying halal and healthy certificates on all types of food and beverages.

In addition to those two, according to Neupane (2015), brand image is a symbol in the mind of every person in distinguishing a product with other products. Brand image is a form of negotiation on product, package, promotion, and advertisement. Based on customer perspective, brand image is the guarantor of reliability and equity of a consumer product. The next concerning factor is customer satisfaction. Customer satisfaction is the realization of the response to products and services, and the results about the characteristics of a product or service. According to Shahroudi and Naimi (2014) satisfaction is mostly described as a customer attitude about the provider of products or services.

Many previous studies have shown a direct correlation that product superiority has an effect on customer satisfaction. According to Haverila and Fehr (2016), customer satisfaction 
is a more important aspect for companies that produce products than for service-based companies. By having brand image and customer satisfaction, the customer is willing to pay for the product. Willingness to pay is one of the important things for the companies because willingness to pay is a challenge for them. When a consumer is willing to buy, the projected profit the company desires can be achieved (Demirgünescedil, 2015).

One of the cafe industries in Indonesia is Starbucks, a coffee shop network from the United States which is based in Seattle, Washington. Starbucks is the world's largest coffee shop with 15,012 outlets in 44 countries. Starbucks sells coffee, espresso-based hot drinks, other hot and cold drinks, snacks, and cups and coffee beans. Starbucks Coffee was first opened in 1971 in Seattle by Jerry Baldwin, Zev Siegle, and Gordon Bowker. The first Starbucks cafés outside of Seattle were in Vancouver and Chicago in 1987 and the first branch outside of North America was located in Tokyo that was opened in 1996.

Excelso is one of the cafes in Indonesia other than Starbucks. Coming from the word "So Excellent" turning into "Excelso", this brand is one of the core players in the cafe industry in the vibrant increase of local and international cafes. Excelso is a subsidiary of PT. Kapal Api, the largest coffee bean producer in Indonesia. Since the opening of the first outlet, Excelso has owned 126 outlets up to now that spread across 16 major cities in Indonesia. In addition to Starbucks and Excelso, there is The Coffee Bean \& Tea Leaf which is founded in 1963. The Coffee Bean \& Tea Leaf serves over 100 million coffee and tea drinks annually all over the world. Providing the highest quality of coffee and tea for over forty years, The Coffee Bean \& Tea Leaf is currently growing both domestically and internationally and has 400 outlets and more all over California, Arizona, Nevada, Hawaii, Singapore, Malaysia, Korea, Brunei, Indonesia, UAE, Israel, Australia, China, Kuwait, Egypt, Qatar and the Philippines. The Coffee Bean \& Tea Leaf has come to Indonesia since 2001 and is managed by PT. Trans Coffee, a group of Trans Corp since 2006. Trans Corp is Indonesia's largest conglomerate company in their growth and success in various consumer sectors including media, entertainment, fashion, retail, food and beverages.

\section{THEORETICAL FRAMEWORK}

Brand Image is a strategic need that helps companies to create more value to customers and also to develop sustainable competitive advantage. A successful brand will increase consumer trust in intangible products and services. Customers will be better in visualizing and identifying their services (Shahroudi and Naimi, 2014).

Neupane's previous research (2015) explained that brand image is a group of mental associations in the customer's perception to increase the value of a product or service. Brand image is also an intangible and conditional asset for a company that is capable in generating company profitability and compromising functional and emotional value. Success category of a company's brand image means capable to generate customer awareness about a brand and optimize company profitability. Brand image can generate values in terms of helping consumers to get information about a company's products or services, get recommendations for buying, differentiate brands among competitors and give positive feelings.

According to Kotler and Keller, (2012) product superiority can be defined as the characteristic differentiation that is found between similar products leading to one product that is considered to have higher value and quality to the customer and or consumer. However, product superiority has different benefits during the service. Therefore, the final product is also a part of customer satisfaction assessment. Services and products are interrelated aspects. Service part includes the beginning and the ending of a purchase plan and covers a number of different phases. Meanwhile, the product is the final part of the relationship with the customer. Each product is interrelated hierarchically with other products. This product hierarchy starts from the basic needs up to certain items that can satisfy those needs.

Customer Satisfaction has been defined in various ways but conceptually, customer satisfaction is the result of the customer's perception of the value in the transaction or the relationship in which the value of the service quality perception is relative to the price and cost of customer acquisition. (Jahanshahi, et al., 2011). Customer satisfaction refers to the 
fulfillment of consumer needs, expectations, or pleasure that comes from the satisfaction. In the marketing literature, customer satisfaction is often defined in terms of temporary shortterm transactions while looking at the importance of overall satisfaction as a long-term process that affects consumer behavior. Operationally, the idea of satisfaction in this research refers to the overall customer satisfaction that comes from previous customer experience in brand consumption.

Customer Satisfaction can also be interpreted as the realization of the response to products and services, as well as the results about the characteristics of goods and services. In fact, customer satisfaction often occurs in customer experience on purchasing and consuming a product. Therefore, customer satisfaction will be measured through customer's satisfaction about the service. Two factors affecting the satisfaction are experience and expectation of service. Practical satisfaction is similar to attitude, so it can evaluate as a collection of satisfaction causes and various features of goods or services (Shahroudi and Naimi, 2014).

Willingness to pay is the willingness of individuals to pay for the goods or services they want. The number of people who are willing to pay depends on the economic value experienced by the consumers on the benefits of the goods. If a person believes that there is no alternative offer, the highest amount of money he/ she wants to pay equals to the quality of the goods and is the ordering price. If a person sees an alternative offer with an economic value under the utility, the highest price he/ she will receive equals to the economic value of the product and is the maximum price (Tully and Winer, 2014).

Willingness to pay is one of the important things for the company because willingness to pay is a challenge for them. By having willingness to pay, the projected profit that is desired by the company can be achieved. Consumer's purchasing intention is based on the perceived value of the product and consumer's willingness to pay for higher prices; loyalty paybacks are obtained when the perceived value is greater. Generally, willingness to pay (WTP) is willingness to pay some money to the consumers to get goods or services. According to Campbell et al, 2014, willingness to pay (WTP) is the maximum price of an item a consumer wants to buy at a particular time.

\section{RESEARCH HYPOTHESES}

Brand image can affect a number of customers to be willing to pay for a product; even some customers are willing to pay higher for similar products from other more relevant brands. Conceptually, according to Anselmsson et al. (2014), they described the brand image as the most useful indicator in the willingness to pay empirically. In addition, brand image is the most important way of willingness to pay where a brand image can create the value of a product. Anselmsson, et al., (2014) even argued that premium prices are the most important way in which brands can create shareholder value because it does not require direct investment to set a higher price. Based on the above description, the following is the proposed hypothesis:

H1: Brand image has a significant effect on willingness to pay.

According to Neupane (2015) a positive brand image has contribution in creating customer satisfaction. In addition, customer satisfaction also has a big role in creating a strong brand image for the company. Therefore, brand image is very important for a company in getting a lifetime loyalty of the customer. By having a brand image, a company can generate values in terms of helping consumers in getting information, generating reasons for purchasing, differentiating brands from competitors, giving positive feelings, and offering basic extensions. Generating and maintaining a successful brand image is an important role of company marketing and branding strategies. Poor brand image may cause a negative influence to the company. Negative influence worryingly decreases customer satisfaction of the company (Neupane, 2015). Based on the above description, the following is the proposed hypothesis:

H2: Brand image has a significant effect on customer satisfaction.

Customer satisfaction is customer's perception of the quality of a product which is based on customer expectations. Customers will compare product quality to their satisfaction 
standard. Customers will be satisfied if the product quality exceeds their standards and customers will be dissatisfied when the product quality is below their standards (Haverila and Fehr, 2016). Customer satisfaction is defined as a benchmark to the extent of the product is successfully received and can serve the customer's expectations. The more challenging the competition in various industries, a company must improve the innovation and skills of individual employees so that the company may produce a product which is in accordance with consumer desires so that the product gets a competitive superiority that meet customer satisfaction. By the fulfillment of customer satisfaction, it will increase the sales and revenue of the company (Haverila and Fehr, 2016). Based on the above description, the following is the proposed hypothesis:

H3: Product has a significant effect on customer satisfaction.

Product is very important to be noticed by a company, especially a manufacturing company because a good product will create a willingness to pay to the consumers. If the company produces good products and the quality is guaranteed then willingness to pay will increase. By the increase of willingness to pay, it will increase product sales then the increase of the sales will also increase the company's profit (Muanas, 2014). The main determinant of willingness to pay for a product is consumer's perception of the utility of a product. The analysis of the market structure with the product is useful in identifying the usage situation in which the more attractive the product form or the more functions and benefits of the product will result the greater the willingness to pay but if the function and benefits of the product is very small then the willingness to pay for the product will also be small (Campbell et al., 2014). Based on the above description, the following is the proposed hypothesis:

H4: Product has a significant effect on willingness to pay.

Satisfaction can be defined as a state in which the consumer has the needs, desires, and expectations that can all be met through the consumed product. Generally, satisfaction can be defined as feelings of pleasure or disappointment of a person from the comparison between the purchased products whether it is in accordance with his/ her expectations or not. Customer satisfaction is very important to maintain consumer willingness to pay, when the consumers feel satisfied with the quality of the products or services provided by the company then consumer willingness to pay will be maintained (Casidy and Wymer, 2016). Customer satisfaction or customer dissatisfaction to the product will affect the following behavior and high satisfaction will create an emotional bond of the customers especially concerning with willingness to pay. If a customer is satisfied he/ she will show a higher probability that can be proved by the higher level of willingness to pay. However, if the customer is not satisfied, it will cause the lower level of willingness to pay. Based on the above description, the following is the proposed hypothesis:

H5: Customer satisfaction has a significant effect on willingness to pay.

\section{METHODS OF RESEARCH}

This research used structural equation modeling (SEM) method that used WarpPLS 5.0 software as the analysis tool. Before the analysis of hypothesis testing, outer model and inner model testing was firstly conducted. Outer model testing examined the correlation between the constructs and the latent variables of the research including discriminate validity, composite reliability, and average variance extracted (AVE). In addition, inner model testing examined the correlation among the latent variables in this research.

The populations of the research were the customer of Coffee Bean outlet in Pakuwon Supermall. The samples of the research were 200 respondents which were in accordance with the minimum limit of CB-SEM. (Ghozali, 2014). Based on the time limitation, the samples of this research were all customers who bought Coffee Bean products in Pakuwon Supermall Surabaya. There was no limitation to how many times the customer bought Coffee Bean product because the research expected to get the respondents evenly both old and new consumers of Coffee Bean product. Therefore, data variability could be obtained in describing customer willingness to pay the product of Coffee Bean in the future. The 
sampling technique to choose the respondent was convenience sampling which meant that the sample selection technique was when the researcher did not have data about the population in the form of sampling frame then the researcher chose the sample based on the principle of easiness in taking or choosing the sample (Abdillah and Hartono, 2015).

\section{RESULTS OF STUDY}

Based on the total of 200 respondents who filled in the questionnaire, information about general description of the respondents and the consumer profile of Coffee Bean are:

Table 1 - Description of Respondent Demography

\begin{tabular}{|c|c|c|c|c|c|}
\hline Respondent Demography & $(\mathrm{N})$ & $\%$ & Respondent Demography & $(\mathrm{N})$ & $\%$ \\
\hline $\begin{array}{l}\text { Gender } \\
\text { Male } \\
\text { Female }\end{array}$ & $\begin{array}{l}88 \\
112\end{array}$ & $\begin{array}{l}44.00 \% \\
56.00 \%\end{array}$ & $\begin{array}{l}\text { Occupation } \\
\text { Civil Servant } \\
\text { Private Employee }\end{array}$ & $\begin{array}{l}8 \\
98\end{array}$ & $\begin{array}{l}4.00 \% \\
49.00 \%\end{array}$ \\
\hline \multirow{2}{*}{$\begin{array}{l}\text { Age } \\
17-30 \text { years } \\
31-40 \text { years } \\
41-50 \text { years } \\
>50 \text { years }\end{array}$} & \multirow{2}{*}{$\begin{array}{l}72 \\
77 \\
30 \\
21\end{array}$} & \multirow{2}{*}{$\begin{array}{l}36.00 \% \\
38.50 \% \\
15.00 \% \\
10.50 \%\end{array}$} & $\begin{array}{l}\text { Entrepreneur } \\
\text { Others }\end{array}$ & $\begin{array}{l}67 \\
27\end{array}$ & $\begin{array}{l}33.50 \% \\
13.50 \%\end{array}$ \\
\hline & & & $\begin{array}{l}\text { Visit Frequency } \\
1 \text { time } \\
2-3 \text { times }\end{array}$ & $\begin{array}{l}120 \\
44\end{array}$ & $\begin{array}{l}60.00 \% \\
22.00 \%\end{array}$ \\
\hline \multirow{2}{*}{$\begin{array}{l}\text { Educational Background } \\
\text { Secondary School } \\
\text { Associate's Degree } \\
\text { Bachelor's Degree } \\
\text { Master's Degree }\end{array}$} & \multirow{2}{*}{$\begin{array}{l}27 \\
18 \\
146 \\
9\end{array}$} & \multirow{2}{*}{$\begin{array}{l}13.50 \% \\
9.00 \% \\
73.00 \% \\
4.50 \%\end{array}$} & $\begin{array}{l}4-5 \text { times } \\
>5 \text { times }\end{array}$ & $\begin{array}{l}30 \\
6\end{array}$ & $\begin{array}{l}15.00 \% \\
3.00 \%\end{array}$ \\
\hline & & & $\begin{array}{l}\text { Payment Method } \\
\text { Member Card } \\
\text { Bank Mega Credit Card } \\
\text { Cash } \\
\text { Others }\end{array}$ & $\begin{array}{l}28 \\
97 \\
51 \\
24\end{array}$ & $\begin{array}{l}14.00 \% \\
48.50 \% \\
25.50 \% \\
12.00 \%\end{array}$ \\
\hline
\end{tabular}

Most of the respondents were female with the percentage of $56 \%$ while the rest were male. Most of Coffee Bean visitors were in the age group between 31-40 years of $38.50 \%$ while the respondents from the age group above 50 years had the smallest percentage of $10.50 \%$.

Table 2 - Research Instrument

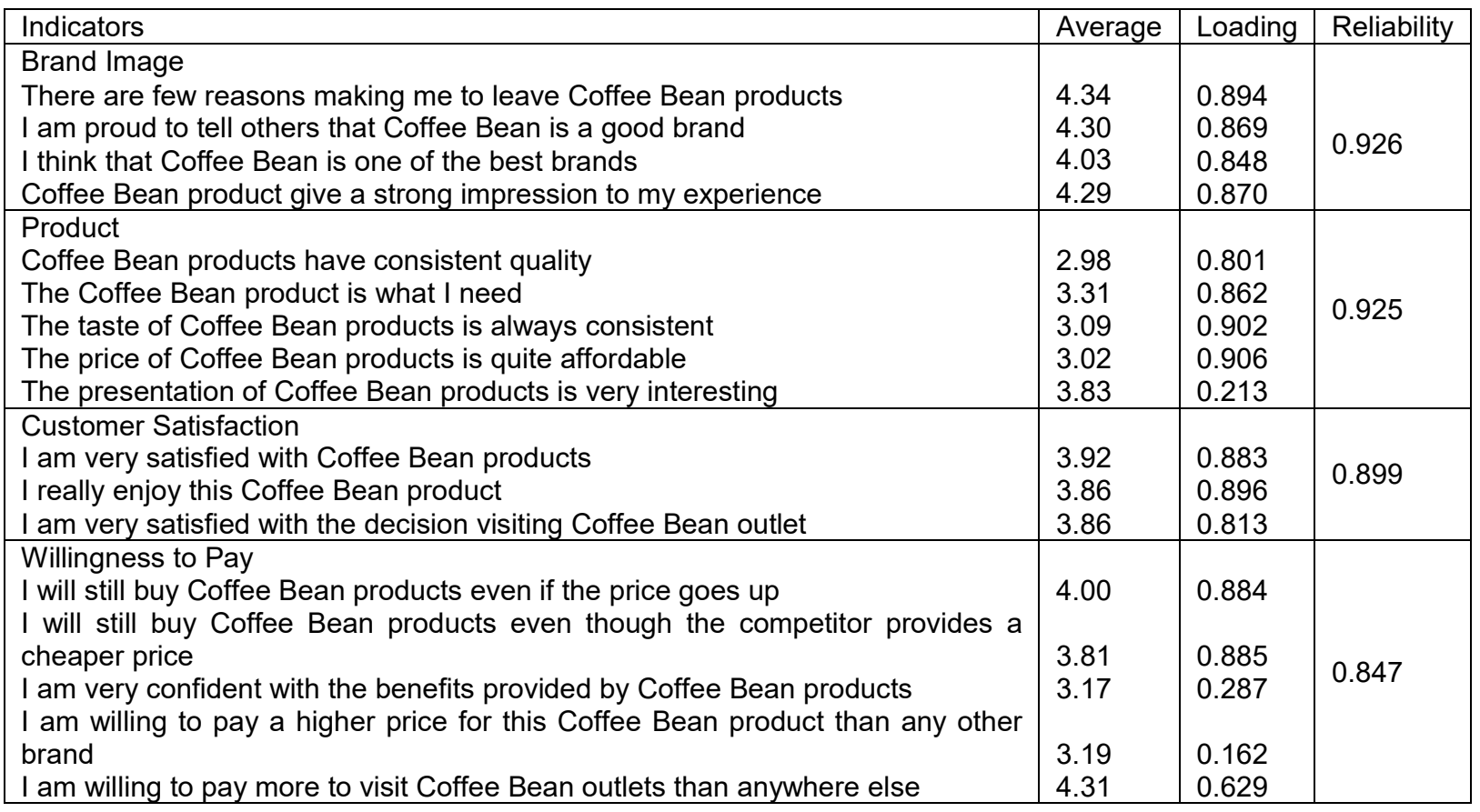

Coffee Bean visitors were consumers who had a fairly high educational background because most of the respondents' educational background was master's degree with the 
percentage of $73 \%$. Respondents of the research had quite diverse occupations including entrepreneurs, private employees, and other jobs. The smallest number of respondents was civil servants with the percentage of $4 \%$ while the largest was private employees with the percentage of $49 \%$. Most of the visitors came to Coffee Bean in the last 1 month only 1 time that was equal to $60 \%$ of the total respondents; it was only a small number of frequent visits more than 5 times. The most widely used payment method to do the transaction at the Coffee Bean was using Bank Mega credit card that was equal to $48.50 \%$ of the total respondents. It was because the use of Bank Mega credit card may get discounts up to $50 \%$. The rest of the respondents used cash, member card of Coffee Bean or debit card.

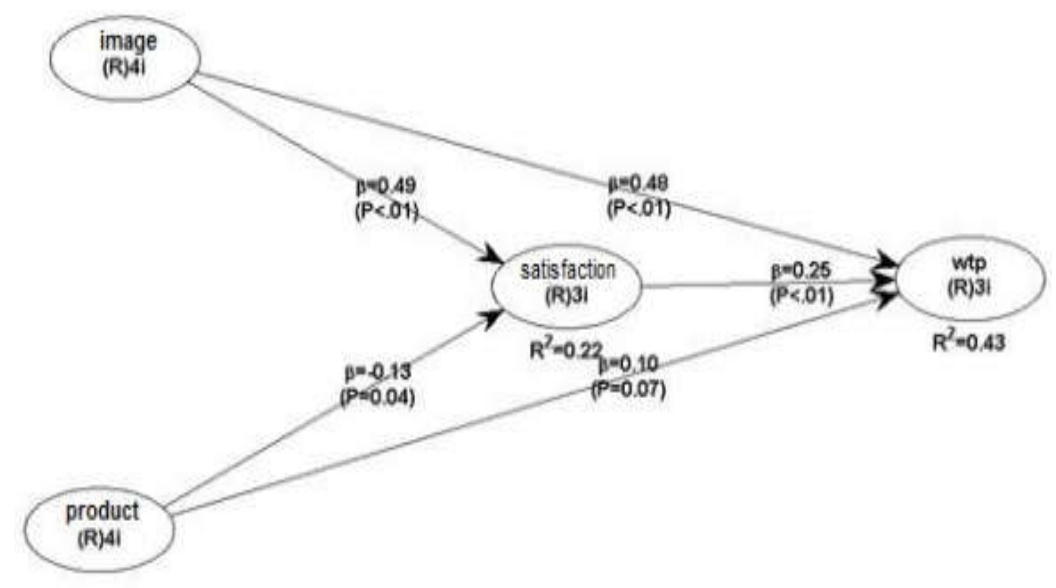

Figure 1 - Research Model

Statistical analysis using WarpPLS 5.0 program was preceded by validity and reliability test to determine the consistency of the measuring instrument whether it was capable to accurately describe the variables to be analyzed. The result of convergent validity test showed that there were 3 variables that do not meet the validity requirement: P5, KM3, and KM4 because their values $<0.05$. Subsequently, the variables must be excluded from the research and validity test. Meanwhile, the construct reliability test had also met the requirement of internal constructs consistency condition because each construct had cronbach alpha value above 0.7 (> 0.7) (Ghozali, 2014).

Table 3 - Hypothesis Testing

\begin{tabular}{|c|l|c|c|c|}
\hline Hypotheses & \multicolumn{1}{|c|}{ Correlation } & P Values & Cut Off Value & Conclusion \\
\hline H1 & Brand Image $\rightarrow$ Willingness to Pay & 0.001 & $<0.05$ & Significant \\
\hline H2 & Brand Image $\rightarrow$ Satisfaction & 0.001 & $<0.05$ & Significant \\
\hline H3 & Product $\rightarrow$ Satisfaction & 0.035 & $<0.05$ & Significant \\
\hline H4 & Product $\rightarrow$ Willingness to Pay & 0.070 & $<0.05$ & Not Significant \\
\hline H5 & Satisfaction $\rightarrow$ Willingness to Pay & 0.001 & $<0.05$ & Significant \\
\hline
\end{tabular}

The research results showed that all hypotheses of the research were acceptable except for hypothesis 4 which stated that there was no significant correlation between the product and the willingness to pay.

\section{DISCUSSION OF RESULTS}

The results of respondents' answers showing the number of 4.24 indicated that the average of all respondents agreed that Coffee Bean had a positive brand image. The brand image was realized by the respondents that Coffee Bean was different from other food and beverages outlets in which Coffee Bean is indeed aimed to the middle and upper class segment. It was known from the design of the place, the price of the offered product, and the service to the consumer. The respondents knew that buying the Coffee Bean products was 
not just buying some drinks but the respondents also use it as a medium to socialize with friends, business relations, enjoy the convenience of the outlet, and show their existences to other people. There was a sense of pride for the respondents if they can buy Coffee Bean products. Thus, from the extra benefits felt by the respondents, then they are willing to pay more.

The results of this research indicated that there was a significant correlation between brand image and willingness to pay. It was in line with the results of a research conducted by Anselmsson, et al (2014), in which the consumer was willing to pay the product at a premium price because it was influenced by the social image, uniqueness, and product originality. As mentioned previously, the brand of Coffee Bean had a positive image for the respondents, the uniqueness of taste and originality of the offered product which were also different from other food and beverage outlet, so this may result the willingness of the respondent to pay more expensive.

The expectations of the respondents had been well met by Coffee Bean, none of the respondents complained about the service quality of Coffee Bean, so the respondents feel happy. Realization received by respondents was so far in line with reality in which it had never been less than what was expected so that the respondents were satisfied buying Coffee Bean products all this time. Coffee Bean was a national franchise restaurant that had the same standard of service and quality between one outlet and other outlets so it provided satisfaction guarantee to all consumers visiting Coffee Bean outlets at everywhere.

The results of this research indicated that there was a significant correlation between brand image and customer satisfaction which was in line with the results of research conducted by Neupane (2015) and Shahroudi and Naimi (2014), in which brand image could determine a consumer to feel satisfied or not satisfied in buying a product. In addition, customer satisfaction will affect customer loyalty to always buy the product. It had been described in this research model that in the research did not discuss about loyalty. This research was only limited to test empirically about how a consumer getting satisfied with a product; one of the response is willing to pay at a higher price.

The result of the respondent's answer, at the number of 3.10 , indicated that the average respondent was less able to describe clearly about the product in Coffee Bean. It was because the products offered by Coffee Bean were almost similar to those offered by other brands including Starbucks, Excelso, and MaxxCoffee. Most of these brands also offered the main drink menu that was almost the same as Coffee Bean; it was coffee. However, in terms of product prices, Coffee Bean had a relatively high price compared to other brands. Respondents were less able to describe specific advantages offered by Coffee Bean products and the difference of Coffee Bean products compared to other brands.

Although Coffee Bean products were perceived equally in consumers mind with other brands, in term of product performance evaluation, the respondents had never experienced a problem. This relatively expensive product was appropriate to the quality given to the respondent. Starting from the raw materials, packaging, taste choices, beverage processing at Coffee Bean, many of these had accommodated the expectations of the respondents so that the product gave a sense of satisfaction for the respondents.

The results of this research, indicating that there was a significant correlation between product and customer satisfaction was in line with the results of research conducted by Haverila and Fehr (2015), in which the product could determine whether the consumers feel satisfied or not in consuming the goods and services. It was undeniable that the respondents came to Coffee Bean not only to enjoy the services offered but also to consume products of Coffee Bean especially coffee drinks. So far, the products sold had been able to meet the expectations of all respondents including in terms of taste and quality so that the product can significantly affected customer satisfaction.

The results also showed that willingness to pay was more affected by brand image variables than product variables. It was related to Coffee Bean products that were often perceived as the same as other competing brands. Meanwhile, the brand image of upper middle-class image had been experienced by the respondents that encouraged them to be 
willing to pay more. Therefore, in other words, most of the respondents who came to Coffee Bean preferred to buy the brand rather than the quality of the product itself.

These insignificant results were also reinforced by the description of the respondents who pointed out that most of Coffee Bean visitors only came 1 time for last month. It indicated that the respondents coming to the outlet were just experimenting with the Coffee Bean brand. They were more familiar with Coffee Bean not from the products but so far from the well-known brand image. Most of the visitors were in the young age below 40 years. The average of their last educational backgrounds was undergraduate degree with the profession as a private employee or entrepreneur. It showed that the visitors were in middle class economic in which where the income earned was enough for just one or two visits to Coffee Bean in one month to just try the beverage, but when the visits were continued to always visit Coffee Bean in a frequent frequency it would have an impact on their financial ability.

The results of this research indicated that there was no significant correlation between product and willingness to pay which was not in line with the results of research conducted by Campbell, et al (2014), in which the product could directly determine the willingness to pay from a consumer in selecting the menu of local food. This difference outcome could be attributed to the fact that the previous research did not include the satisfaction variable that might affect willingness to pay.

Various responses from satisfied customers were willing to pay more, repurchasing, and were loyal to that particular brand. In term of loyalty, most of respondents are not really loyal customers to the brand of Coffee Bean. It was supported by descriptive data that $60 \%$ of respondents only ever visited Coffee Bean 1 time in the last 1 month. Besides, most respondents had also tried to move to other brand competitors.

So far, all respondents were satisfied with the service and products provided by Coffee Bean because it had been in accordance with the expectation so it was reasonable if the respondents were willing to pay more. That satisfaction could be realized because the price of Coffee Bean products were relatively expensive so it was worth with the convenient place (the ordinary Coffee Bean outlet was located in large malls of every big city), very friendly service from the crews, as well as good taste of the food and beverage.

The results of this research showed that there was a significant correlation between customer satisfaction and willingness to pay which was in line with the results of research conducted by Chaudhuri and Ligas (2016), and Casidy and Wymer (2016) in which the research proved that satisfied customers were willing to pay more to get the products.

\section{CONCLUSION AND SUGGESTIONS}

This research aimed to explain the factors affecting the level of willingness to pay from Coffee Bean consumers. The result of hypothesis testing showed that hypotheses 1, 2, 3, and 5 from the research were acceptable. Hypothesis number 4 was unacceptable because it formed insignificant correlation between the product and willingness to pay.

This research also had some limitations, including 1) not choosing the respondents at all Coffee Bean outlets in Surabaya so the description of the data distribution questionnaires was uneven, 2) most of respondents had only visited Coffee Bean 1 time in the last 1 month, so it was less precise to ask them describing customer satisfaction and the willingness to pay, 3) the variables under research were very limited on brand image, customer satisfaction, and product. Another new variable could be added in the following study.

The following are some suggestions that can be used for further similar research: 1) According to Coffee Bean, the competition between coffee outlets on the market today is very tough, especially when this sector is controlled by some big brands such as Starbucks, Coffee Bean, Excelso, and also MaxxCoffee. In terms of product, price, service, outlets design, and promotion to the four brands, they are almost known as equal for the people who do not have a meaningful difference between these brands. To win the competition in the coffee shop industry, Coffee Bean must have the right product strategy, which is a very authentic and different product from other coffee outlets. The result of the questionnaire showed that the average of respondents' answers to the product variables was neutral. It 
was indicated that during this time, the respondents still felt hesitant to come to Coffee Bean just to buy the product. The product of Coffee Bean was lack of determinant factor of a respondent so that they were willing to pay more than other similar products. So far, the willingness of respondents to pay more was more influenced by the brand image of Coffee Bean itself. It was expected that the implementation of the right product marketing strategy, the brand image of Coffee Bean will become more positive to the people, increase customer satisfaction, and the desire to pay more also increase so that brand profitability and equity of Coffee Bean is very strong among consumers. 2) For further research, it is expected to complete the shortcomings of the limitations in this research. Further research is also expected to develop this research by taking another variable so that the analysis can be obtained widely and deeply.

\section{REFERENCES}

1. Abdillah, W., \& Hartono, J. (2015). Partial Least Square (PLS): Alternatif Structural Equation Modeling (SEM) dalam Penelitian Bisnis. Yogyakarta: Penerbit Andi.

2. Anselmsson, J., Vestman Bondesson, N., \& Johansson, U. (2014). Brand image and customers' willingness to pay a price premium for food brands. Journal of Product \& Brand Management, 23(2), 90-102.

3. Campbell, J., DiPietro, R. B., \& Remar, D. (2014). Local foods in a university setting: Price consciousness, product involvement, price/quality inference and consumer's willingness-to-pay. International Journal of Hospitality Management, 42, 39-49

4. Casidy, R., \& Wymer, W. (2016). A risk worth taking: Perceived risk as moderator of satisfaction, loyalty, and willingness-to-pay premium price. Journal of Retailing and Consumer Services, 32, 189-197.

5. Chaudhuri, A., \& Ligas, M. (2016). The Role of Store Trust and Satisfaction in Creating Premium Prices. Marketing Management Journal, 26(1).

6. Demirgünescedil, B. K. (2015). Relative Importance of Perceived Value, Satisfaction and Perceived Risk on Willingness to Pay More. International Review of Management and Marketing, 5(4).

7. Ghozali, I. (2014). Structural Equation Modeling. Metode alternatif dengan Partial Least Squares (PLS), Badan Penerbit Universitas Diponegoro, Semarang.

8. Haverila, M. J., \& Fehr, K. (2016). The impact of product superiority on customer satisfaction in project management. International Journal of Project Management, 34(4), 570-583.

9. Jahanshani, A. A., Hajizadeh, G. M. A., Mirdhamadi, S. A., Nawaser, K., \& Khaksar, S. M. S. (2014). Study the effects of customer service and product quality on customer satisfaction and loyalty.

10. Kotler, P \& Keller, K.L. (2012). Marketing Management. Fourteenth Global Edition. Pearson Education .

11. Muanas, A. (2015). Pengaruh Produk, Harga Dan Promosi Terhadap Keputusan Pembelian Mobil Buana Indomobil Trada. Jurnal Ilmu \& Riset Manajemen, 3(12).

12. Neupane, R. (2015). The effects of brand image on customer satisfaction and loyalty intention in retail super market chain UK. International Journal of Social Sciences and Management, 2(1), 9-26.

13. Shahroudi, K., \& Naimi, S. S. (2014). The impact of brand image on customer satisfaction and loyalty intention (case study: consumer of hygiene products). International Journal of Engineering Innovations and Research, 3(1), 57.

14. Tully, S. M., \& Winer, R. S. (2014). The role of the beneficiary in willingness to pay for socially responsible products: a meta-analysis. Journal of Retailing, 90(2), 255-274. 